\title{
ESSAYS
}

\section{Sexual Orientation and the Constitution: A Note on the Relationship Between Due Process and Equal Protection}

\author{
Cass R. Sunstein $\dagger$
}

In Bowers $v$ Hardwick, ${ }^{1}$ the Supreme Court held that the due process clause does not protect the right to engage in homosexual sodomy. The Court said that heightened judicial protection under that clause was reserved to rights "implicit in the concept of ordered liberty" or "deeply rooted in this Nation's history and tradition." According to the Court, homosexual sodomy could not qualify for special protection under either test. ${ }^{3}$

In some circles, Hardwick was thought to spell the end, at least for the immediate future, to efforts to use constitutional litigation to prevent government from imposing sanctions on the basis of sexual orientation. In Padula $v$ Webster, ${ }^{4}$ for example, the United States Court of Appeals for the District of Columbia Circuit upheld the FBI's policy of considering homosexual conduct a "significant" and often dispositive factor in employment decisions. The court said that the issue was controlled by Hardwick:

It would be quite anomolous [sic], on its face, to declare status defined by conduct that states may constitutionally criminalize as deserving of strict scrutiny under the equal protection

$\dagger$ Karl N. Llewellyn Professor of Jurisprudence, Law School and Department of Political Science, The University of Chicago. Bruce Ackerman, Cynthia Chessick, David Currie, Richard Epstein, Barbara Flagg, Richard Fallon, Larry Kramer, Geoffrey Miller, Judith Resnik, Geoffrey R. Stone, David Strauss, and Laurence Tribe provided helpful comments on an earlier draft.

478 US 186 (1986).

2 Id at 191-92, quoting Palko $v$ Connecticut, 302 US 319, 325 (1937) and Moore v East Cleveland, 431 US 494, 503 (1977) (Powell opinion).

3 Id at 192.

- 822 F2d 97, 99 (DC Cir 1987). 
clause. ... If the Court was unwilling to object to state laws that criminalize the behavior that defines the class, it is hardly open to a lower court to conclude that state sponsored discrimination against the class is invidious. ${ }^{5}$

What the Padula court described as an anomaly became the holding of United States Court of Appeals for the Ninth Circuit in Watkins $v$ U.S. Army. ${ }^{\circ}$ There the court concluded that the equal protection component of the Due Process Clause forbids the Army from discriminating on the basis of sexual orientation. ${ }^{7}$ The court so held in spite of Hardwick and Padula, and in the face of a vigorous dissent from Judge Reinhardt. Judge Reinhardt predicted that "a wiser and more enlightened Court" would overrule Hardwick and, indeed, described that decision in exceedingly harsh terms: "I believe that the Supreme Court egregiously misinterpreted the Constitution in Hardwick. . . . I believe that history will view Hardwick much as it views Plessy v Ferguson . . . ." In Judge Reinhardt's view, however, the Hardwick decision compelled the conclusion that the Army's policy did not offend the Constitution.

In this essay, I make two claims. The first is quite narrow. In spite of appearances, Hardwick-strictly as a matter of doctrine-was interpreted correctly in the majority opinion in Watkins, ${ }^{\circ}$ and misread in Padula and Judge Reinhardt's dissenting

- Id at 103.

- 847 F2d 1329 (9th Cir 1988), reh'g granted, en banc 847 F2d 1362 (1988).

7 Since Watkins involved a federal measure, no question was raised under the Equal Protection Clause of the Fourteenth Amendment. The court relied instead on the equal protection component of the Fifth Amendment's Due Process Clause, initially recognized in Bolling v Sharpe, 347 US 497, 499 (1954). See 847 F2d at 1335 n 9. For purposes of the present discussion, the phrases "equal protection component of the Due Process Clause" and "Equal Protection Clause" will be used interchangeably. Again for present purposes, it may be assumed that the basic antidiscrimination principles applicable to the states are also applicable to the federal government. In some contexts, however, that assumption is highly questionable. See, for example, Mathews v Diaz, 426 US 67 (1976) (Medicare eligibility statute distinguishing among aliens does not violate Due Process Clause of Fifth Amendment).

847 F2d at 1358.

- Much of the Watkins opinion emphasizes that the relevant Army regulation discriminates on the basis of homosexual status rather than homosexual acts. See 847 F2d at 1338, 1343. This feature of the opinion serves to distinguish Hardwick in a persuasive way: if the relevant acts are not at issue in Watkins, Hardwick does not control.

It would, however, be a mistake to conclude that the Equal Protection Clause freely permits discrimination against a class of gays and lesbians, even if some, many, or even all of them engage in activity that may be regulated consistently with the Due Process Clause. The principal thrust of the Watkins decision-emphasizing unjustified hostility, past and present, against gay men-supports that conclusion. See 847 F2d at 1345-49. Watkins can be distinguished from Hardwick even if the former decision were to be applied to a class of people including some, many, or all who engage in the conduct at issue in Hardwick. 
opinion in Watkins. Properly understood, the Hardwick decision does not resolve the issue in Watkins and Padula.

My second, somewhat broader claim is that the disagreement over the meaning of Hardwick contains a larger lesson for the relationship between the Due Process and Equal Protection Clauses. That lesson is structural, and operates even in the face of different views about how hard cases should be resolved under the two clauses. From its inception, the Due Process Clause has been interpreted largely (though not exclusively) to protect traditional practices against short-run departures. The clause has therefore been associated with a particular conception of judicial review, one that sees the courts as safeguards against novel developments brought about by temporary majorities who are insufficiently sensitive to the claims of history. ${ }^{10}$

The Equal Protection Clause, by contrast, has been understood as an attempt to protect disadvantaged groups from discriminatory practices, however deeply engrained and longstanding. The Due Process Clause often looks backward; it is highly relevant to the Due Process issue whether an existing or time-honored convention, described at the appropriate level of generality, is violated by the practice under attack. By contrast, the Equal Protection Clause looks forward, serving to invalidate practices that were widespread at the time of its ratification and that were expected to endure. The two clauses therefore operate along different tracks.

Because of the independence of the lines of analysis under the two clauses, the conclusion in Hardwick does not dispose of the issue in Watkins. This claim suggests that the Equal Protection Clause is a natural route for constitutional protection against discrimination on the basis of sexual orientation;11 and that, more

${ }^{10}$ For examples of this conception of judicial review, see Alexander M. Bickel, The Least Dangerous Branch, ch 3 (Yale, 2d ed 1986); Harlan F. Stone, The Common Law in the United States, 50 Harv L Rev 4, 25 (1936); Lochner v New York, 198 US 45, 76 (1905) (Holmes dissenting). For a recent example, see James M. Buchanan, Contractarian Political Economy and Constitutional Interpretation, 78 Am Econ Rev 135, 139 (May 1988) ("The function of the judiciary is protection of that which is . . . The judicial branch properly serves a stabilizing rather than a reformist ... role. The courts should protect what is rather than try to promote what might be ....").

${ }^{11}$ I do not discuss in this essay the complex issues raised by the claim that discrimination on the basis of sexual orientation is a form of discrimination on the basis of sex. Advocates of that position argue that discrimination on the basis of sexual orientation is (a) at least on its face, a form of sex discrimination; (b) part of a system of sex role stereotyping; and (c) even if in not readily apparent ways, a method of disadvantaging women. See Sylvia A. Law, Homosexuality and the Social Meaning of Gender, 1988 Wisc L Rev 187. See also Adrienne Rich, Compulsory Heterosexuality and Lesbian Existence, in Blood, Bread and Poetry 23 (Norton, 1986); Note, From This Day Forward: A Feminine Moral Discourse on 
generally, statutes that are unaffected by the Due Process Clause may be drawn into severe doubt by principles of equal protection.

\section{The Reach of Bowers V HaRDWICK}

A

Perry Watkins enlisted in the Army in 1967, at the age of 19. The pre-induction medical form asked whether Watkins had homosexual tendencies; he answered "yes."12 The Army found Watkins qualified for admission and inducted him. In 1975, the Army convened a board of officers to decide whether Watkins should be terminated because of his homosexual tendencies. Watkins's commanding officer testified that he was "the best clerk I have ever known," that he did "a fantastic job - excellent," and that Watkins's open homosexuality did not affect the company. ${ }^{13}$ A sergeant stated that Watkins's sexual orientation was widely known but that it caused no problems among other soldiers. The board unanimously recommended that Watkins be retained "because there is no evidence suggesting that his behavior has had either a degrading effect upon unit performance, morale or discipline, or upon his own job performance."14

In 1977, Watkins was initially denied a position in the Nuclear Surety Personnel Reliability Program; the ground for denial was Watkins's statements about his sexual orientation. Watkins's commanding officer requested that he be requalified for the position, stating that Watkins was "one of our most respected and trusted soldiers, both by his superiors and his subordinates" and that "[f]rom daily personal contacts I can attest to the outstanding professional attitude, integrity, and suitability ... of . . W Watkins."15 The decision to deny Watkins a position in the nuclear program was reversed.

In 1980, Watkins's security clearance was revolked because of his sexual orientation. In 1981, the Army issued a regulation mandating the discharge of all homosexuals. ${ }^{16}$ In the same year, an army board voted to discharge Watkins because of his revelation of his sexual orientation. Watkins brought suit in federal district

Single Gender Marriage, 97 Yale L J (forthcoming 1988); Loving $v$ Virginia, 388 US 1 (1967) (invalidating miscegenation law).

12 Watkins, 847 F2d at 1330.

${ }_{13}$ Id at 1331.

14, Id.

${ }^{15} \mathrm{Id}$.

${ }^{26}$ Id at 1332. 
court. ${ }^{17}$ While the action was pending, the Army rated Watkins's performance and professionalism, giving him a score of 85 out of 85 possible points. The Army's written statement said that "Watkins is without exception, one of the finest Personnel Action Center Supervisors I have encountered. . . . He requires no supervision . . . . Watkins' potential is unlimited."18

The district court held that Watkins's discharge violated neither the Constitution nor any relevant statute. ${ }^{19} \mathrm{~A}$ divided court of appeals reversed, holding that the discharge violated the Equal Protection Clause. The court concluded that Bowers $v$ Hardwick did not resolve the equal protection issue, that discrimination on the basis of sexual orientation should be subject to heightened judicial scrutiny, and that the Army could not meet its burden of justification. $^{20}$

B

If Hardwick is examined in simple lawyerly terms, the majority in Watkins appears to have understood the reach of the decision correctly. There was no equal protection issue before the Supreme Court in Hardwick. The plaintiffs invoked the Due Process Clause, complaining that the Georgia prohibition on consensual sodomy was an impermissible invasion of constitutional privacy. The Georgia statute did not classify on the basis of sexual orientation. ${ }^{21}$ Indeed, the Supreme Court said, in explicit terms, that its conclusion did not deal with principles of equal protection. ${ }^{22}$ At first glance, then, the result in Hardwick does not bear on challenges, brought on equal protection grounds, to discrimination on the basis of sexual orientation.

It is hardly unusual, however, for a decision not directly dealing with an unanswered question to have powerful implications for that question, or implicitly to resolve it. This view underlies both the Padula decision and Judge Reinhardt's dissenting opinion in Watkins. In Padula, the court of appeals suggested that it would

17 Id.

18 Id at 1333-34.

10 The district court granted an injunction in 1982. On appeal, the Ninth Circuit reversed and remanded to the district court for determination of whether the regulation violated the Constitution or any statute. 721 F2d 687 (9th Cir 1983). On remand, the district court held that the regulation was lawful. 551 F Supp 212 (WD W Va 1988).

20 Watkins, 847 F2d at 1340, 1349, 1352.

21 See Ga Code Ann \& 16-6-2 (1984).

22478 US at $196 \mathrm{n} 8$ ("Respondent does not defend the judgment below based on the Ninth Amendment, the Equal Protection Clause or the Eighth Amendment."). In fact, the respondent raised an equal protection problem in a footnote, but the Court ignored it. See Brief for Respondents at $28 \mathrm{n} 60$. 
be quite strange to hold that the Constitution allows the state to criminalize certain conduct, but at the same time that it forbids the state to discriminate against those who engage in that very conduct." In the same vein, Judge Reinhardt argued that "when conduct that plays a central role in defining a group may be prohibited by the state, it cannot be asserted with any legitimacy that the group is specially protected by the Constitution." 24

At first glance, there is a powerful logic to this view. After Bowers $v$ Hardwick, the Constitution does not protect homosexual acts from criminalization. Since it does not, it may appear peculiar to suggest that participation in conduct that may constitutionally be criminalized can help to entitle a group to special constitutional protection. $^{25}$

Despite appearances, there is no peculiarity in this suggestion. In Hardwick, the Court did not answer the question whether a state may constitutionally criminalize heterosexual sodomy. Whether the Court had answered that question in the affirmative or in the negative, its answer would not have prevented a plaintiff from resorting to the Equal Protection Clause to challenge a statute discriminating on the basis of sexual orientation or, indeed, criminalizing homosexual but not heterosexual sodomy. ${ }^{26}$ It should make no difference if the question of heterosexual sodomy remains undecided.

More generally, the Equal Protection Clause is aimed at classifications. The question in Padula and Watkins was whether discrimination against a subgroup of people, some or many of whom engage in conduct that can constitutionally be criminalized, is a

${ }^{23} 822$ F2d at 103. It should be unnecessary to point out, however, that not all gays and lesbians engage in the conduct at issue in Hardwick.

24847 F2d at 1357.

${ }^{25}$ As we will see, this way of phrasing the issue in Watkins is misleading, not least because many members of the class penalized by the Army regulation did not engage in the conduct at issue in Hardwick.

${ }^{26}$ See note 84 and accompanying text. As elaborated below, the Hardwick case has no relevance to a statute challenged on the ground that it discriminates on the basis of sexual orientation; such a statute would have no necessary connection with homosexual acts. Moreover, it is important to understand that a statute that discriminates between people who have engaged in homosexual acts, and people who have not, does not in fact discriminate on the basis of sexual orientation. Some people of heterosexual orientation have engaged in homosexual acts; some people of homosexual orientation have not engaged in homosexual acts. For reasons suggested below, a statute discriminating on the basis of sexual orientation should be subject to special scrutiny under the Equal Protection Clause; the same considerations also support the view that statutes should be subject to such scrutiny if they discriminate on the basis of participation in homosexual acts, though I do not argue that point in detail here. 
violation of the Equal Protection Clause. Nothing in Bowers $v$ Hardwick purports to answer that question. The fact that the underlying conduct can be criminalized is irrelevant to the problem; it is always immaterial to an equal protection challenge that members of the victimized group are engaging in conduct that could be prohibited on a general basis. ${ }^{27}$

The principal flaw in both Padula and Judge Reinhardt's dissenting opinion in Watkins is that they read the Constitution as an undifferentiated unit, rather than as a set of entitlements and prohibitions that are targeted at quite discrete problems. Each constitutional provision must be taken on its own. It would hardly be odd to find that one constitutional provision invalidates practices about which another provision has nothing to say. The Fourth Amendment, for example, does not disable the state from regulating activities that the First Amendment protects, and vice versa. The fact that the Fourth Amendment does not prevent the state from regulating all speech-related activities could not plausibly be a reason to immunize speech from special First Amendment scrutiny. ${ }^{28}$ Such phenomena can be found throughout constitutional law. As we shall see, results of this sort should be especially unsurprising for the Due Process and Equal Protection Clauses.

To clarify the point in the context of Watkins, it is useful to imagine that there is no privacy principle in the Constitution, or that the Due Process Clause is purely procedural. ${ }^{20}$ Suppose that in such circumstances a plaintiff brings a suit challenging, under the Due Process Clause, a statute criminalizing consensual homosexual sodomy. The constitutional challenge would of course fail, for the Due Process Clause-containing no privacy principle or being limited to procedure-does not bar the law in question. The fact that a purely procedural Due Process Clause, or a Clause with-

${ }^{27}$ To this extent, the Watkins court is persuasive in suggesting an analogy to discrimination against (for example) blacks who engage in acts that may constitutionally be prohibited. $847 \mathrm{~F} 2 \mathrm{~d}$ at 1340 . The fact that the underlying conduct may be banned does not mean that a classification against some people who engage in that conduct is permissible. The analogy is imperfect, however, because it has already been decided that blacks are entitled to special judicial protection; the question in Watkins was whether gays and lesbians are entitled to such protection in the face of Hardwick.

${ }^{28}$ See Stanley v Georgia, 394 US 557 (1969).

29 Positions of this sort are defended in, for example, David P. Currie, The Constitution in the Supreme Court ch 11 at 363-82 (Chicago, 1985); Robert H. Bork, Neutral Principles and Some First Amendment Problems, 47 Ind L J 1, 8-11 (1971). The view that the Due Process Clause is without substantive content has of course been repeatedly rejected by the Court. See for example Roe $v$ Wade, 410 US 113 (1973); Moore $v$ East Cleveland, 431 US 494 (1977). 
out a privacy principle, does not protect homosexual conduct would have no bearing on the question whether some other clause forbids the state from singling out gays and lesbians for special disability. The two questions are entirely unrelated. Or suppose that a ban on consensual homosexual activity were challenged as violative of the First Amendment or the Takings Clause. Such a challenge would in all likelihood ${ }^{30}$ fail; but the failure would have no consequences for an attack brought under the Equal Protection Clause.

The situation in Watkins was quite similar. The Supreme Court based its decision in Bowers $v$ Hardwick on the view that the scope of substantive due process should be defined largely by reference to tradition. Thus the Court looked to whether homosexual sodomy was "implicit in the concept of ordered liberty" or "deeply rooted in this Nation's history and tradition." 31 But a holding that the Due Process Clause extends thus far and no farther does not affect the equal protection claim, which is founded on a different set of values. As we will see, the Equal Protection Clause is a self-conscious repudiation of history and tradition as defining constitutional principles. Analysis of an equal protection claim therefore proceeds along an entirely distinct track. To say this is not to provide the affrmative argument for the outcome in Watkins. It is, however, to suggest that the Hardwick decision simply does not bear on the problem in that case, and that in this respect the Watkins majority was correct.

In short, the question after Hardwick is not whether it is illogical to hold that those who engage in acts that can be criminalized might by virtue of that fact qualify as a suspect class. The question is instead whether it is anomalous to conclude that a class that includes people who engage in acts substantively unprotected by the Due Process Clause can be entitled to judicial protection against official discrimination. In view of the different functions of the Due Process and Equal Protection Clauses, an affirmative answer to that question would produce no anomaly.

Indeed, close parallels to this sort of reasoning can be found in a long line of cases in existing law. The "fundamental rights" branch of equal protection doctrine is self-consciously designed to prohibit states from drawing impermissible lines with respect to rights that the Due Process Clause does not substantively protect. For example, discrimination with respect to the right to vote and

${ }^{31} 478$ US at $191-92$. 
the right to appeal is prohibited even though the states may eliminate both rights. ${ }^{32}$ Similarly, the Court has barred distinctions affecting the right to marry ${ }^{33}$ and the right to procreate ${ }^{34}$ while assuming that those rights are substantively unprotected by the Due Process Clause. The Court's decision in Eisenstadt $v$ Baird ${ }^{35}$ was also in this tradition, invalidating a distinction between the rights of the married and the unmarried to obtain contraceptives without holding that there was a substantive right of access to contraception. In this sense, there is nothing at all unusual in the Watkins court's conclusion that the Equal Protection Clause forbids classifications with respect to practices that the Due Process Clause does not independently protect from state control. ${ }^{36}$

The principal objection to this line of argument stems from the way the Court constructed its opinion in Hardwick. In the Supreme Court, the plaintiffs challenged the regulation of consensual sodomy on due process grounds. ${ }^{37}$ The plaintiffs did not speak only in terms of sexual orientation. It was the Court that understood the case as presenting an issue of regulation of homosexual conduct rather than of sodomy in general. ${ }^{38}$ The Court upheld the statute only insofar as it applied to consensual homosexual sodomy. The Court reserved the question whether the statute would be valid if applied to heterosexual sodomy. ${ }^{39}$ In this way, the Court itself drew a line between homosexual and heterosexual conduct, upholding regulation of the first but not necessarily the second. The problem, in short, is this: if Watkins is correct, the very line drawn by the Supreme Court in Hardwick violates the Equal Protection Clause. On this view, it is quite odd to suggest that Hardwick did not at least implicitly resolve the equal protection problem.

The first difficulty with this line of argument is that it disregards the fact that Hardwick was self-consciously styled as an interpretation of the Due Process Clause. The Court itself said that respondent did not defend the judgment below on the basis of the

${ }^{32}$ See Harper $v$ Virginia Bd. of Elections, 383 US 663 (1966); Griffin $v$ Illinois, 351 US 12 (1956).

${ }^{33}$ See Zablocki v Redhail, 434 US 374 (1978).

* Skinner v Oklahoma, 316 US 535 (1942).

${ }^{35} 405$ US 438 (1972).

${ }^{36}$ The difference lies in the fact that Watkins relies on the "suspect class" branch of equal protection, whereas Eisenstadt and related cases are rooted in the "fundamental rights" branch. That difference, however, seems immaterial for present purposes.

37 Brief for Respondents 8-9.

ss Hardwick, 478 US at 190.

39 Id at $188 \mathrm{n} 2$. 
Equal Protection Clause, and that disclaimer would be puzzling indeed if the Court's interpretation of the Due Process Clause were understood to resolve the equal protection issue.

The larger point is that it may be plausible to interpret the Due Process Clause to permit the regulation of homosexual sodomy but to proscribe the regulation of heterosexual sodomy. ${ }^{40}$ Such an interpretation would not, however, immunize from attack on equal protection grounds a law that drew a line between heterosexuals on the one hand and gays and lesbians on the other. In its substantive dimension, the Due Process Clause protects a range of basic rights; it does not speak to the constitutionality of classifications. It is in this respect that the Equal Protection Clause operates as a functional complement to the Due Process Clause, addressing a different set of questions. For this reason, it would not be anomalous for the Equal Protection Clause to prohibit the state from drawing lines that a tradition-based Due Process Clause itself incorporates. In order to support that view, however, it will be necessary to talk more generally about the relationship between the Due Process and Equal Protection Clauses.

\section{Due Process and Equal Protection}

The discussion thus far has suggested that purely as a doctrinal matter, the court of appeals was correct in concluding that the due process ruling in Hardwick had no bearing on the equal protection issue in Watkins. That claim reveals a more fundamental point. From its origin, the Due Process Clause has often been interpreted so as to protect traditionally recognized rights from state and federal power. ${ }^{41}$ Nothing in the text of the clause compels such a conclusion, and on this point as on others the history is ambigu-

40 That question is beyond the scope of the present discussion. It is notable, moreover, that at the very most, the Hardwick Court distinguished between homosexual and heterosexual acts; it did not draw any line between homosexual and heterosexual people, as did the Army regulation at issue in Watkins. 847 F2d at 1336-37 n 11. For reasons already discussed, that line raises distinctive considerations under the Equal Protection Clause.

"11 At its inception, however, the Due Process Clause had a kind of equal protection dimension as well. The clause grew out of requirements in English law that the executive must comply with "the law of the land." See C.H. McIlwain, Due Process of Law in Magna Carta, 14 Colum L Rev 27, 44-49 (1914); Edward S. Corwin, The Doctrine of Due Process of Law Before the Civil War, 24 Harv L Rev 366, 368-70 (1911). Such requirements imposed a principle of generality and equal treatment. The Executive was thereby barred from imposing criminal disabilities on whomever he happened to choose. The evenhandedness function of the Due Process Clause thus has an equal protection component. That component is, however, distinct from the function of the Equal Protection Clause in providing special protection for disadvantaged groups. 
ous. ${ }^{42}$ But in its judicial interpretation, the clause has frequently been understood as an effort to restrict short-term or shortsighted deviations from widely held social norms; it has an important backward looking dimension. For purposes of due process, the baseline for inquiry has tended to be the common law, AngloAmerican practice, or the status quo. The Due Process Clause is thus closely associated with the view that the role of the Supreme Court is to limit dramatic and insufficiently reasoned change, to protect tradition against passionate majorities, and to bring a more balanced and disinterested perspective to bear on legislation.

The point should not be overstated. There are a number of important qualifications. Tradition has not been and should not be the exclusive focus of the Court's due process jurisprudence. But this basic understanding has played a large role in the Court's decisions on substantive due process-a point central to the opinion in Hardwick itself. Indeed, it is on the surface of many of the most important substantive due process cases. Hence the early incorporation decisions attempted to defend their outcomes by reference to notions deeply held in Anglo-American law. In Murray's Lessee $v$ Hoboken Land and Improvement Co. ${ }^{43}$ the Court suggested that the content of the Due Process Clause would be defined by reference "to those settled usages and modes of proceeding existing in the common and statue [sic] law of England ...."44 In Twining $v$ New Jersey, ${ }^{45}$ the Court asked whether the right in question is a "fundamental principle of liberty and justice which inheres in the very idea of free government," as to which tradition would be critical. ${ }^{46}$ In the most important of recent incorporation cases, Duncan $v$ Louisiana, ${ }^{47}$ the Court examined whether "a procedure is necessary to an Anglo-American regime of ordered liberty," a question that would be answered by an exploration of "actual systems bearing virtually every characteristic of the common-law system that has been developing contemporaneously in England and in this country." 48

Quite outside of the area of incorporation, a number of the

12 See Frank H. Easterbrook, Substance and Due Process, 1982 S Ct Rev 85, 95 (arguing that the Fifth Amendment and the Bill of Rights generally were understood as a "nondegradation principle" designed to ensure that things would not "get worse.").

43 59 US 272 (1855).

44 Id at 277.

45211 US 78 (1908).

$18 \mathrm{Id}$ at 106.

47391 US 145 (1968).

48 Id at 149-50 n 14. 
substantive due process cases are rooted in similar instincts. For example, the Court's principal decisions in the Lochner period were based on the Due Process Clause. ${ }^{48}$ In those cases, the Court viewed deviations from common law standards with considerable skepticism. Regulation that interfered with the existing allocation of property rights was treated as impermissibly partisan and as constitutionally suspect. ${ }^{\text {s0 }}$ A large part of the reason for this skepticism was that the relevant regulation departed significantly from common law norms; public law was thus defined by reference to traditional private law. ${ }^{51}$ There is, of course, a broad consensus that the relevant cases were wrongly decided. The central point here is about structure, not about particular outcomes. The Court's skepticism about departures from what it perceived as historical understandings of property rights fits comfortably with a traditionbased conception of substantive due process.

In cases involving limitations on state court jurisdiction, the Court has spoken in the same terms. In International Shoe Co. $v$ Washington," the Court said that the question is whether "the maintenance of the suit" transgresses "traditional notions of fair play and substantial justice." used in the more recent cases as well..$^{54}$

The most controversial and important of the modern substantive due process cases of course involve privacy. ${ }^{55}$ These cases also depend importantly on references to tradition. The theme is made explicit in the majority and concurring opinions in Griswold $v$ Connecticut. ${ }^{56}$ It is also present in Moore $v$ East Cleveland, ${ }^{57}$ where Justice Powell wrote,

Appropriate limits on substantive due process come . . . from careful 'respect for the teachings of history [and] solid recognition of the basic values that underlie our society.'. . . Our (1923).

19 Lochner $v$ New York, 198 US 45 (1905); Adkins v Children's Hospital, 261 US 525

${ }^{\text {so }}$ See Laurence H. Tribe, American Constitutional Law $\$ 8-1$ (Foundation, 2d ed 1988); Cass R. Sunstein, Lochner's Legacy, 87 Colum L Rev 873, 874 (1987).

si See Pennsylvania Coal v Mahon, 260 US 393, 413 (1922).

32326 US 310 (1945).

s3 Id at 316, quoting Milliken v Meyer, 311 US 457, 463 (1940).

s4 Burger King Corp v Rudzewicz, 471 US 462, 476-78 (1985); World-Wide Volkswagen Corp. $v$ Woodson, 444 US 286, 292 (1980).

${ }^{85}$ Griswold v Connecticut, 381 US 479 (1965); Eisenstadt v Baird, 405 US 438 (1972); Carey $v$ Population Services International 431 US 678 (1977); Roe v Wade, 410 US 113 (1973).

s6 381 US 479 (1965).

s7 431 US 494 (1977). 
decisions establish that the Constitution protects the sanctity of the family precisely because the institution of the family is deeply rooted in this Nation's history and tradition. ${ }^{58}$

Despite rhetoric of this sort, the Court's privacy jurisprudence cannot be understood exclusively in these terms. It is a familiar point that the use of tradition has produced considerable awkwardness in the cases. The principal difficulty lies in determining the contours and reach of the relevant tradition. Traditions can be described at varying levels of generality. There may well be, for example, a tradition of respect for intimate association. The application of that tradition has hardly been consistent, however, and the hard cases arise when the general tradition of respect meets a particular context in which the general tradition has been repudiated and, to that extent, does not exist at all. There is no established tradition of protection of abortion, marital privacy, or use of contraception. In the hard cases, part of the question is whether the tradition should be read at a level of generality that draws the particular practice into question. ${ }^{58}$ Many of the important privacy cases read the role of tradition in precisely this way.

In short, the tradition cannot by itself be controlling in close cases, and the constitutional question must be answered instead by an inescapably normative inquiry into how the relevant tradition is best characterized. ${ }^{\circ 0}$ As a result, the tradition is sometimes treated as aspirational. The Court has referred in some key cases to "evolving standards of decency," as to which tradition is relevant but not dispositive. ${ }^{61}$ It is for this reason, among others, that the Court's decision in Hardwick itself is extremely troublesome. ${ }^{62}$ Indeed, it is here that the Hardwick Court erred in its treatment of the privacy problem. ${ }^{63}$ At the level of generality that best explains such decisions as Roe and Griswold, the governing tradition would

${ }^{58}$ Id at 503, quoting Griswold, 381 US at 501 (Harlan concurring).

so For discussion of some of the difficulties in using tradition as a source of constitutional decision, see, for example, John Hart Ely, Democracy and Distrust 60-63 (Harvard, 1980); Tribe, American Constitutional Law at 1311, 1426-29 (cited in note 50). In deciding the relevant level of generality, norms of equal protection become extremely important. See Hardwick, 478 US at 214 (Stevens dissenting).

${ }^{60}$ See Ronald Dworkin, Law's Empire ch 2 (Belknap/Harvard, 1986) (stressing the interpretive character of law).

61 See, for example, Trop v Dulles, 356 US 86, 101 (1958).

${ }^{62}$ See, for example, Tribe, American Constitutional Law at 1311, 1426-27 (cited in note 50); Hardwick, 478 US at 204-08 (Blackmun dissenting); Watkins, 847 F2d at 1353-58 (Reinhardt dissenting); Thomas B. Stoddard, Bowers v. Hardwick: Precedent by Personal Predilection, 54 U Chi L Rev 648 (1987).

${ }^{3}$ See sources cited in note 62 . 
require far stronger justification than did the Hardwick Court for criminal bans on sexual activity between consenting adults.

The point here, however, is not to explore the relationships among tradition, Hardwick, and the rest of the privacy cases. It is instead to suggest that the Due Process Clause has called for an inquiry with a significant historical dimension, that the Hardwick decision turned on precisely this fact, and that a large part of the function of the clause has been to limit myopic or short-term deviations from social convictions that have been long and widely held. The Court's function as provider of a "sober second thought" which to measure legislation is most evident in its use of the Due Process Clause.

Since its inception, the Equal Protection Clause has served an entirely different set of purposes from the Due Process Clause. The Equal Protection Clause is emphatically not an effort to protect traditionally held values against novel or short-term deviations. The Clause could not be characterized as a "nondegradation principle" designed to ensure that things will not "get worse." implausible to describe the role of the Supreme Court, under the Equal Protection Clause, as the provision of a sober second thought to legislation or the defense of tradition against pent-up majorities. The clause is not backward-looking at all; it was selfconsciously designed to eliminate practices that existed at the time of ratification and that were expected to endure. ${ }^{66}$

The function of the Equal Protection Clause is to protect disadvantaged groups, of which blacks are the most obvious case, against the effects of past and present discrimination by political majorities. The scope of the Clause and the precise content of the equality norm are of course deeply disputed. ${ }^{67}$ But on any view, the Equal Protection Clause is not rooted in common law or status quo baselines, or in Anglo-American conventions. The baseline is instead a principle of equality that operates as a criticism of existing practice. The clause does not safeguard traditions; it protects against traditions, however long-standing and deeply rooted.

This difference accounts for the fact that Supreme Court deci-

as See generally Bickel, The Least Dangerous Branch (cited in note 10).

Bs Easterbrook, $1982 \mathrm{~S} \mathrm{Ct} \mathrm{Rev} \mathrm{at} 95$ (cited in note 42).

${ }^{\text {B }}$ See Charles Fairman, Does the Fourteenth Amendment Incorporate the Bill of Rights? The Original Understanding, 2 Stan L Rev 5 (1949). Brown v Board of Education, 347 US 483 (1954) is the most obvious illustration of judicial endorsement of this point.

${ }^{67}$ See Owen M. Fiss, Groups and the Equal Protection Clause, 5 Phil \& Pub Affairs 107, 108 (1976); Paul Brest, Foreword: In Defense of the Antidiscrimination Principle, 90 Harv L Rev 1, 5 (1976). 
sions that reject common law or status quo baselines usually rely on the Equal Protection Clause. ${ }^{68}$ Cases involving the protection of disadvantaged groups are, of course, the most conspicuous examples of this. ${ }^{69}$ But it should be no surprise that the Equal Protection Clause has also been the source of decision in cases involving such matters as voting rights, ${ }^{70}$ access to court, ${ }^{71}$ and disparities in education. ${ }^{72}$

This approach also has implications for the privacy cases. In particular, it suggests that there is much to be said in favor of the mounting academic consensus ${ }^{73}$ that Roe $v$ Wade involved issues of sex discrimination as well as privacy, and that the problem of abortion might plausibly have been approached in equal protection terms. Laws that restrict reproductive rights burden women exclusively; they are closely associated with traditional ideas about the role of women in the raising of children, ideas that have played a part in sex discrimination. The reason that it is both possible and problematic to treat cases involving reproductive rights in terms of due process is the same: the relevant tradition is highly ambiguous. It may be that the Equal Protection Clause will ultimately prove to be a preferable source of decision, though in order to defend the outcome in Roe, the argument would have to be quite elaborate. ${ }^{74}$

However these more difficult questions may be resolved, there is a large difference in the basic functions of the Due Process and Equal Protection Clauses. The decision of the Court of Appeals in Watkins therefore contains a lesson for doctrinal development under the two clauses. The Due Process Clause may sometimes

${ }^{68}$ See Sunstein, 87 Colum L Rev at 913 (cited in note 50).

69 See, for example, Graham v Richardson, 403 US 365 (1971) (aliens); Frontiero $v$ Richardson, 411 US 677 (1973) (women); Trimble v Gordon, 430 US 762 (1977) (nonmarital children); Cleburne v Cleburne Living Center, Inc., 473 US 432 (1985) (mentally retarded).

70 See for example Harper v Virginia Board of Elections, 383 US 663 (1966); Kramer $v$ Union Free School District No. 15, 395 US 621 (1969).

${ }^{71}$ See for example Griffin $v$ Illinois, 351 US 12 (1956); Douglas v California, 372 US 353 (1963). See also the disagreement between Justices Douglas and Harlan on whether litigation access fees raise problems of due process or equal protection in Boddie $v$ Connecticut, 401 US 371 (1971).

72 See Plyer v Doe, 457 US 202 (1982).

${ }^{73}$ See Tribe, American Constitutional Law at 1353-56 (cited in note 50); Catharine MacKinnon, Feminism Unmodified ch 8 (Harvard, 1987); Kenneth L. Karst, Foreword: Equal Citizenship Under the Fourteenth Amendment, 91 Harv L Rev 1, 53-59 (1977); Frederick Schauer, Easy Cases, 58 S Cal L Rev 399, 431-32 n 83 (1985); Ruth Bader Ginsburg, Some Thoughts on Autonomy and Equality in Relation to Roe v Wade, 63 NC L Rev 375 (1985); David Strauss, Discriminatory Intent and the Taming of Brown (unpublished manuscript on file with The University of Chicago Law Review).

7 See preceding note for preliminary efforts. 
permit traditions that the Equal Protection Clause proscribes, even if those traditions are rooted in discrimination-a point that both Eisenstadt and Watkins make clear.

This is hardly the space for a full-scale defense of the argument that classifications on the basis of sexual orientation should be subject to heightened scrutiny under the Equal Protection Clause, an argument that has been made in detail in many places. ${ }^{75}$ And there is reason for uncertainty about whether the current Supreme Court will accept that argument, especially in the context of the military. ${ }^{28}$

It may be suggested, however, that the majority opinion in Watkins correctly emphasized the history of discrimination against gays and lesbians and the likelihood that challenged measures will reflect past and present prejudice. ${ }^{77}$ Empathetic identification on the part of the majority is peculiarly unusual in this setting. Statutes and regulations that discriminate on the basis of sexual orientation often reflect fear and hostility that are not susceptible to rational justification. ${ }^{78}$ The rationale accepted in Hardwick as sufficient for due process purposes-relating principally to traditionally held moral norms-has little or no weight in the context of an equal protection challenge; consider the Court's rejection of such norms in the areas of race and sex discrimination. The Watkins court also pointed to the peculiar difficulty of using political avenues to seek redress ${ }^{79}$ and the usual irrelevance of sexual orienta-

75 Watkins, 847 F2d at 1345-49. See also Note, The Constitutional Status of Sexual Orientation: Homosexuality as a Suspect Classification, 98 Harv L Rev 1285, 1297 et seq (1985); Note, An Argument for the Application of Equal Protection Heightened Scrutiny to Classifications Based on Homosexuality, $57 \mathrm{~S}$ Cal L Rev 797 (1984); Bruce A. Ackerman, Beyond Carolene Products, 98 Harv L Rev 713, 740-46 (1985); Tribe, American Constitutional Law at 1616-17 (cited in note 50).

${ }^{78}$ Rostker $v$ Goldberg, 453 US 57 (1981) (deferring to legislative decision not to register women for the draft); Greer $v$ Spock, 424 US 828 (1976) (allowing regulation of speech on military bases).

$77847 \mathrm{~F} 2 \mathrm{~d}$ at $1345-49$.

${ }^{78}$ See Ely, Democracy and Distrust at 162-63 (cited in note 59) (discussing prejudice against homosexuals).

79 847 F2d at 1348-49. The problem here stems in part from the fact that gays and lesbians are subject to widespread social hostility. As a result, disclosure of homosexuality creates a series of risks of social sanctions, ranging from various forms of social ostracism to dismissal from employment to private violence. It is for this reason, among others, that the exercise of political power by gays and lesbians is unusually difficult. See Ackerman, 98 Harv L Rev at 728-31 (cited in note 75); Ely, Democracy and Distrust at 162-64 (cited in note 59).

Ordinary equal protection law, embodied in United States v Carolene Products Co., 304 US 144 (1938), depends on crude understandings about political organization. Discreteness and insularity may increase rather than decrease the capacity to exert political influ- 
tion to legitimate governmental goals. ${ }^{80}$ In these respects, the pattern of discrimination on the basis of sexual orientation is strikingly analogous to the pattern of discrimination against blacks. Particularly notable is the Watkins court's treatment of the relationship between immutability and equal protection problems. $^{81}$

The arguments used to justify exclusion of gays and lesbians from the military are the same arguments that were once used to allow discrimination on the basis of race and sex. Those justifications refer primarily to adverse effects on military morale and discipline, adverse effects that are a product of private biases. ${ }^{82}$ The record in Watkins suggests that those arguments are no more persuasive here than there. The general argument for heightened scrutiny of classifications based on sexual orientation applies regardless of the weight of the justifications in particular cases, and regardless of the possibility that the military presents special considerations arguing in favor of judicial deference. ${ }^{83}$

It may be useful to conclude by suggesting that the legal regime produced by Watkins is coherent even in the face of Hardwick. Watkins makes it generally impermissible to single out gays

ence, and among the most important sources of real world political failure is the undue influence of well organized private groups as against diffuse, poorly organized majorities. See Geoffrey P. Miller, The True Story of Carolene Products, 1987 S Ct Rev 397, 404-06, 42228; Ackerman, 98 Harv L Rev at 734-37 (cited in note 75). The insights of modern public choice theory thus bear significantly on the theory of equal protection.

It would be a large mistake, however, to use those insights in order to suggest that equal protection problems can be approached solely through a non-normative understanding (assuming that such a thing could be imagined) of the problems of political organization in the particular case. As the defining case of blacks reveals, the question whether a group deserves special solicitude under the Equal Protection Clause depends on an inescapably normative inquiry into the legitimacy of the reasons ordinarily used to disadvantage that group. Although such an inquiry will ask whether political organization is feasible in the circumstances, it cannot be limited to that question.

80 847 F2d at 1346.

81 "Although the causes of homosexuality are not fully understood, scientific research indicates that we have little control over our sexual orientation and that, once acquired, our sexual orientation is largely impervious to change.[citations omitted]. Scientific proof aside, it seems appropriate to ask whether heterosexuals feel capable of changing their sexual orientation. Would heterosexuals living in a city that passed an ordinance banning those who engaged in or desired to engage in sex with persons of the opposite sex find it easy not only to abstain from heterosexual activity but also to shift the object of their sexual desires to persons of the same sex?" 847 F2d at 1347-48 (emphases in original).

${ }^{22}$ See Watkins, 847 F2d at 1350: "These concerns strike a familiar chord. For much of our history, the military's fear of racial tension kept black soldiers separated from whites." Note also that in the context of Watkins, the concern about blackmail was quite weak. " $[\mathrm{H}]$ omosexuality poses a special risk of blackmail only if a homosexual is secretive about his or her sexual orientation." Id at 1352.

${ }^{83}$ See note 76 (cases reflecting judicial deference in matters concerning the military). 
and lesbians for special disabilities; differential treatment of that sort will face a large burden of justification. So long as Hardwick remains the law, however, measures that proscribe certain sexual activities may be upheld against a due process attack so long as the prohibitions apply regardless of sexual orientation. ${ }^{84}$ The requirement of generality operates as a political safeguard, ensuring that if the heterosexual majority is to burden gays and lesbians, it must burden itself as well. In imposing this requirement of generality, the Equal Protection Clause, as understood in Watkins, serves its most familiar and established function.

\section{Conclusion}

The Watkins court's interpretation of Bowers $v$ Hardwick was correct. The court of appeals in Padula, and Judge Reinhardt in his dissenting opinion in Watkins, misconstrued the Hardwick decision. The conclusion that the Due Process Clause does not protect consensual homosexual sodomy does not resolve the question whether principles of equal protection forbid discrimination on the basis of sexual orientation. ${ }^{85}$

84 The qualification is necessary because Hardwick left open the possibility that heterosexual sodomy is constitutionally protected. According to the view presented here, of course, an equal protection attack would be available in those jurisdictions that banned homosexual but not heterosexual sodomy. See note 26. But see Baker $v$ Wade, 769 F2d 289 (5th Cir 1985) (en banc) (upholding such a statute). Watkins itself need not be understood to go that far, however, since the decision applies to distinctions based on sexual orientation rather than on the nature of sexual acts.

ss For purposes of the present discussion, I put to one side some of the other difficulties with using Hardwick to dispose of claims of unconstitutional discrimination on the basis of sexual orientation. To list just a few:

(1) Sometimes a civil disability might be imposed on gays and lesbians in jurisdictions in which there is no criminal prohibition on homosexual acts. In such a jurisdiction, Hardwick is of uncertain relevance. It is by no means clear that the fact that the state could criminalize the relevant acts is sufficient to support discrimination in circumstances in which the state has chosen to impose no such criminal disability.

(2) It is unclear that the state's power to criminalize homosexual acts includes the authority to impose unique or distinctive civil disabilities on a class of people that includes many who engage in such acts. Imagine, for example, a law prohibiting gays and lesbians from teaching in the public schools. Even if homosexual acts may be criminalized, it remains necessary to explain why a class including many who engage in such acts, and not other criminal acts, are being forced to suffer civil sanctions. The problem becomes more severe in light of the fact that the civil sanctions appear weakly related to legitimate state purposes.

(3) Discrimination against people of homosexual orientation is different from discrimination against people who engage in acts that are and can constitutionally be criminalized-as the Watkins court emphasized. The difference is important in at least two ways. First, members of the relevant class may not have engaged in the prohibited acts at all. Second, discrimination on the basis of sexual orientation has some of the characteristics of a status offense as prohibited in Robinson v California, 370 US 660 (1962). 
The conclusion of the Watkins court also contains a large and often overlooked lesson about the relationship between the Due Process and Equal Protection Clauses. The Due Process Clause is backward-looking; a large part of its reach is defined by reference to tradition. The clause is closely associated with, even if not limited to, the view that the role of the Court is to protect against illconsidered or short-term departures from time-honored practices. The Equal Protection Clause, by contrast, is grounded in a norm of equality that operates largely as a critique of traditional practices. The Watkins decision provides reason to believe that constitutional protection against discrimination on the basis of sexual orientation will ultimately take place under the Equal Protection Clause. It should be unsurprising if such developments occur even in the wake of Bowers $v$ Hardwick. 
